\title{
CHRYSOSTOM ON LETTERS AND LETTER-WRITING
}

\section{Introduction}

Christianity was a movement of letter-writers. ${ }^{1}$ More than nine thousand letters ${ }^{2}$ written by Christians in antiquity have been preserved for us. More specifically, collections of extant letters from the patristic golden age are surprisingly numerous and large. ${ }^{3}$ Yet, in 1973 Doty ${ }^{4}$ said, "up to the present time epistolary research has remained scattered and fragmentary. There are few if any comprehensive treatments of the epistle in English, and to my knowledge there is no small but inclusive presentation of the epistolary literature of late Hellenism and primitive Christianity...". Since then several good publications in this field of study have come to light, ${ }^{5}$ but the situation has still not improved drastically. There is therefore still much work to be done. Chrysostom, for example, was an ardent letter-writer, and we possess more than 240 letters of his. ${ }^{6}$ However, these letters have not been properly studied to this day. But not only these letters, but also his oth-

(1) S. K. Stowers, Letter Writing in Greco-Roman Antiquity (Philadelphia: Westminster Press, 1989) 15.

(2) I will not make a distinction between a letter and an epistle. Adolf Deissmann was criticized for his sharp distinction between "letter" and "epistle"; cf. A. J. Malherbe, Ancient Epistolary Theorists (Atlanta: Scholars Press, 1988) 1.

(3) M. R. P. McGuire, Letters and Letter Carriers in Christian Antiquity, The Classical World 53 (1960) 152.

(4) W. G. Dоту, Letters in Primitive Christianity (Philadelphia: Fortress Press, 1973) ix.

(5) For example the series: G. H. R. Horsley, and S. R. Llewelyn, New Documents Illustrating Early Christianity (Australia: Macquarie University, 1984-) and H.-J. KLAuck, Ancient Letters and the New Testament: A Guide to Context and Exegesis (Waco: Baylor University Press, 2006).

(6) P. Allen and W. Mayer, John Chrysostom, in: P. F. Esler (ed.), The Early Christian World (London: Routledge, 2000) 1131. See also P. R. ColemanNorton, The Correspondence of S. John Chrysostom (with special reference to his Epistles to Pope S. Innocent I), Classical Philology 24 (1929) 279. 
er works give us valuable information on the art of writing letters, and also on the practice of the reading of letters of his time. In this paper we will discuss the place and function of letters in the ancient world based on what Chrysostom tells us about this issue. This information will open up for us interesting aspects of the social life of people in Chrysostom's society, since letters are, more than any other genre, embedded in the social contexts and interactions of particular historical moments. ${ }^{7}$ We will also see how Chrysostom uses his knowledge on letter-writing to explain certain aspects of the New Testament letters.

One should remember that ancient societies were more stable than ours and were not subject to the same rapid changes that we are used to. That is why it is valid to use information that Chrysostom gives to interpret Biblical literature from four centuries earlier. Chrysostom, for example, would often refer to a New Testament practice and then

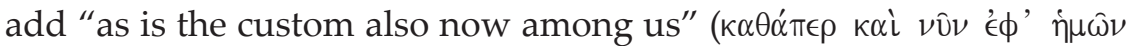
$\left.\epsilon^{\epsilon} \sigma \tau \iota \nu\right) .{ }^{8}$ This shows that there were still very many similarities between the world of the New Testament and the world of Chrysostom.

\section{The Function of Letters}

Letters played a very important role in the ancient world. Chrysostom tells us that the Athenians even made a public monument of the epistles of Plato. ${ }^{9}$ It is, however, unclear what this monument looked like.

In the hands of someone who cannot read, an epistle is merely paper $(\chi \alpha \dot{\alpha} \rho \tau \nu)$ and ink $\left(\mu \mu^{\prime} \lambda \alpha \nu\right) .{ }^{10}$ But a person who can read "will both hear a voice and will hold converse with the absent." The function of the letter is therefore to connect the author and the reader. But one could also ask someone else to write a letter on their behalf. One could then merely dictate one's message to that person. Chrysostom calls

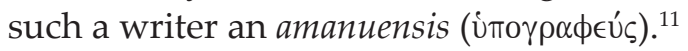

(7) Cf. S. K. Stowers, Greek and Latin Letters, in: D. N. Freedman (ed.), The Anchor Bible Dictionary (New York: Doubleday, 1992) IV. 290.

(8) In epistulam ii ad Thessalonicenses, PG 62, 469. 42-43.

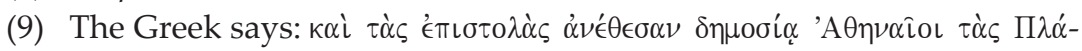
$\tau \omega \nu$ s. It is difficult to translate the Greek, but it seems that the meaning is that the Athenians erected a public monument of the epistles of Plato. Perhaps Chrysostom means that these letters were copied onto stone as inscriptions (cf. Stowers, Greek and Latin Letters, IV. 291).

(10) In epistulam $i$ ad Corinthios, PG 61, 56. 14.

(11) In epistulam ad Romanos, PG 60, 677. 45-46. 
Most people were eager to receive letters from friends. ${ }^{12}$ Writers of letters always longed to receive a reply from their addressees. ${ }^{13}$ And when they received a reply on their letter, they were even more willing to reply again and that led to a vital exchange of letters between correspondents. ${ }^{14}$ Letters were also often read over and over again, with much thoroughness. ${ }^{15}$

Yet, people were not always eager to read or to listen to letters which were being read. It was much easier to listen to an orator. It there-

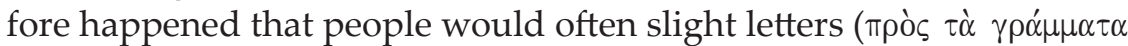

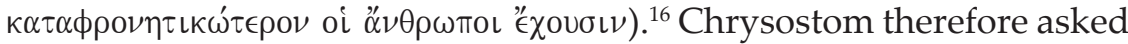

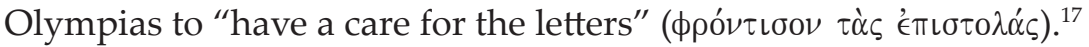

\section{Addressees and Subject Matter}

Friends wrote letters to one another. Chrysostom sent a letter to his friend Theodore. ${ }^{18}$ In this letter he pleaded with his friend Theodore to return to the monastic life. He also wrote several letters to Olympias to cheer her up. ${ }^{19}$ And he also wrote another letter to check the excess of

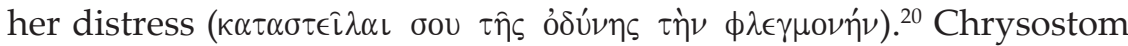
pleaded with Olympias that she write him a letter to inform him about her state of health. ${ }^{21}$ He said that she should also write to him and tell him whether her despondency had left her. ${ }^{22}$ She had told him that her sickness was caused by her despondency. ${ }^{23}$ Later on Chrysostom emphasized that despondency could cause bodily infirmity. ${ }^{24}$

There was also a lively correspondence between church officials. We hear about the bishop Hilarius who asked Chrysostom permission to go to his own country to attend to matters and to come back there-

(12) Epistulae ad Olympiadem 17, 1. 44-48.

(13) Ad Theodorum lapsum lib. ii. sec. vi. 20-24.

(14) Epistulae ad Olympiadem 9. 5. 5-7.

(15) Ibid., 9. 4. 36-39.

(16) In epistulam $i$ ad Timotheum, PG 62, 505. 58-59.

(17) Epistulae ad Olympiadem 9. 5. 51.

(18) Ad Theodorum lapsum lib. ii.

(19) Epistulae ad Olympiadem 17. 1. 44-48; 10. 1. 14-16.

(20) Ibid., 8. 1. 2.

(21) Ibid., 2. 1. 9.

(22) Ibid., 2. 1. 1112.

(23) Ibid., 17. 1. 44-48.

(24) Ibid., 17. 4. 43-47. 
after. ${ }^{25}$ Chrysostom wrote to him and also to the elder Helladius. We have also letters from Chrysostom to Innocent, bishop of Rome, and vice versa. ${ }^{26}$ Chrysostom discussed ecclesiastical events in the Church at Alexandria with Innocent, bishop of Rome. ${ }^{27}$ Stowers ${ }^{28}$ says that the letter was an important tool for the changing church. It was not a matter of the lone itinerant apostle and his fellow workers struggling to build small churches over a large area. Letters even caused local disputes to become empire-wide theological controversies.

\section{The Emperor and Letters}

It was very common for people to write letters to the Emperor. ${ }^{29}$ In the morning the king would sit on his throne in the royal courts. His officials would then bring to him innumerable letters which were sent to him from all quarters. ${ }^{30}$ They could also send letters to the Emperor to ask him to show mercy. These letters to the Emperor would be read in the court. ${ }^{31}$ The judges made notes and later on it was brought to the notice of the Emperor.

The Emperor also wrote letters to his people. He would, for example, announce new taxes by sending out letters. ${ }^{32}$ He even wrote letters on ecclesiastical matters. Chrysostom tells us, for example, that they asked the Emperor to convene a synod. The emperor would then send out imperial letters ( $\gamma \rho \alpha \mu \mu \alpha \dot{\tau} \omega \nu \beta \alpha \sigma \iota \lambda \iota \kappa \omega \nu)$ in every direction $\left(\pi \alpha \nu \tau \alpha \chi 0 \hat{} \delta\left\llcorner\alpha \pi \epsilon \mu \phi \theta^{\prime} \epsilon \tau \tau \omega \nu\right)\right.$, convoking men from all quarters $(\pi \alpha \dot{\alpha} \nu \tau 0 \theta \epsilon \nu$

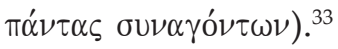

The Emperor could also send letters $(\gamma \rho \alpha \dot{\mu} \mu \mu \alpha \tau \alpha)$ to release prison-

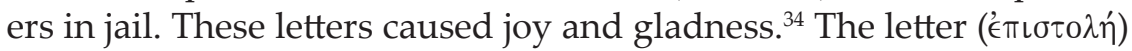
of the Emperor needed only a few words $(\gamma \rho \alpha \dot{\alpha} \mu \mu \alpha \alpha)$ when he wanted to set free those who were liable to countless accusations. ${ }^{35}$ Similarly,

(25) Epistulae ad Olympiadem 9. 5. 42-53.

(26) Ad Innocentiam 52. 530ff.

(27) Ad Innocentium papam 52. 530ff.

(28) Stowers, Letter Writing..., 44.

(29) De sancton hieromartyre Babyla, PG 50, 533. 14.

(30) De profectu evangelii, $P G 51,314.32-36$.

(31) Ad populum Antiochenum 49. 174. 58-175. 2.

(32) Ibid., 49. 73. 3-7.

(33) Ad Innocentiam papam 52. 532. 41-48.

(34) In Acta apostolorum, PG 60, 26. 10-11; cf. also PG 60, 365. 26-27.

(35) Ad illuminandos catecheses, PG 49, 227. 1-5. 
with a mere letter consisting of a few words he could also assign the highest honour to other people. ${ }^{36}$

These letters of the Emperor obviously carried the authority of a decree, but they were nevertheless called letters. Paul's letters were

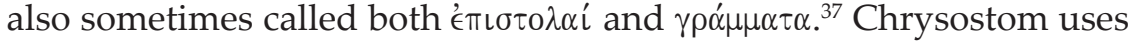

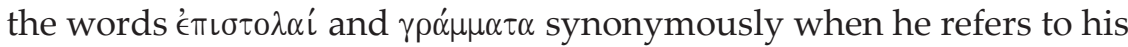
own letters ${ }^{38}$ and when he refers to letters of other people. ${ }^{39}$ The only difference between the use of these two words is that when the word $\gamma \rho \alpha \dot{\alpha} \mu \alpha \alpha \tau \alpha$ is used to refer to letters, it is always used in the plural, while the word $\epsilon \pi \iota \sigma \tau 0 \lambda \eta$ can be used in both the singular or plural.

Chrysostom praised the Emperor for writing a letter at Easter-time to instruct the liberation of everybody in prison. He did this out of respect for Easter and said: "If only it were possible for me to raise even

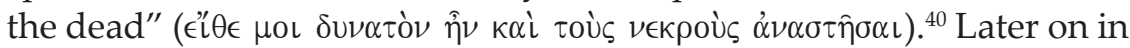
387 at Antioch a mob threw down and demolished the statues of the Imperial family in a sedition caused by the imposition of extra tax. The Emperor was furious and considered destroying the city entirely. The people were in fear and Chrysostom then comforted them by telling them that when the Emperor arrives, the priest would read this selfsame letter to the Emperor and remind him of his own philanthropy.

\section{The Reception of Imperial Letters}

When the letters $(\gamma \rho \alpha \dot{\alpha} \mu \alpha \tau \alpha)$ of a king were about to be read in a the-

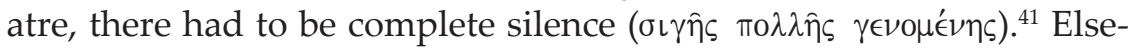

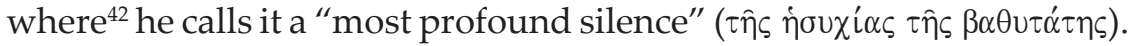
Everybody had then to be composed ("丷天 $\pi \alpha \nu \tau \alpha \varsigma \delta \in \hat{\imath} \kappa \alpha \tau \epsilon \sigma \tau \alpha \dot{\alpha} \lambda \theta \alpha \iota)$ and had

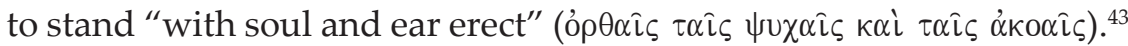
Chrysostom refers to this practice in his time in order to convince his

(36) Ad illuminandos catecheses, PG 49, 227. 1-5.

(37) In epistulam ad Romanos, PG 60, 671. 57-67; 395, 672. 5-7.

(38) Ad Theodorum lapsum lib. ii. sec. vi. 4-6; cf. also Epistulae ad Olympiadem 9. 4. 31-32.

(39) De profectu evangelii, PG 51, 314. 34-37; Epistulae ad Olympiadem 2. 1. 7-13; 2. 1. 19-20; 10. 1. 14-16.

(40) Ad populum Antiochenum 49. 84. 32-47.

(41) In Matthaeum, PG 57, 24. 18-19.

(42) Ibid., 285. 24.

(43) Ibid., 24. 18-19. 
congregation that they too should maintain a mystic silence ( $\sigma \iota \gamma \eta \hat{\varsigma} \varsigma \mu \nu \tilde{\sigma}$

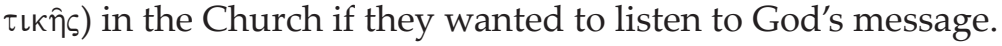

Chrysostom lists all the people who had to stand up, namely the

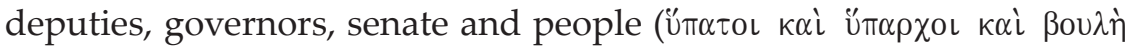
$\kappa \alpha \iota \delta \bar{\eta} \mu \mathrm{s}) .{ }^{44}$ It seems that he adheres to protocol since he names them from the highest to the lowest rank, from the deputies to the people! Chrysostom adds that if someone should suddenly leap up and cry out, he would suffer the utmost punishment, since such an action

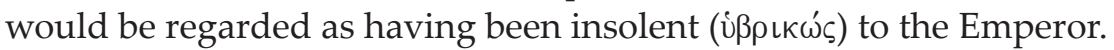

It is not clear whether the people were summoned to the theatre primarily to listen to the reading of the emperor's letters, or whether the emperor's letters were read in the theatre since everybody was already in the theatre to watch another event. However, Chrysostom refers in another homily as well to the people in the theatre who had to maintain silence in order that the letters of the emperor could be read. In that homily he refers to the people in the theatre as oi $\theta \epsilon \alpha \tau \alpha i$ (the spectators).$^{45}$ One may perhaps deduct from this that the imperial authorities used the visitors to the theatre as a captive audience to listen to the message of the Emperor.

But letters from the Emperor were also read in the Church. Chrysostom says that when there were matters of importance ( $\pi \epsilon \rho i$ $\tau \iota \nu \omega \nu$ $\dot{\alpha} \nu \alpha \gamma \kappa \alpha i \omega \nu)$, the emperor would send a person wearing a golden girdle (' $\chi \omega \omega \nu \zeta \omega ́ \eta \nu \chi \rho \nu \sigma \eta \hat{\nu) . ~}{ }^{46}$ People were always eager to come to the church to listen to what was written in these imperial letters. It was not even necessary for the deacon to ask them to be quiet when the person with the golden girdle stood up to read the letters. They paid attention to the message. Chrysostom says that he often noticed this when letters of the kings were read in his church. He then complains that his congregation was less eager to come to the Church to listen to the Word of God.

(44) In Matthaeum, PG 57, 285. 24.

(45) Ibid., 285. 20.

(46) In epistulam ii ad Thessalonicenses, PG 62, 484. 46-57. 


\section{Letter-Carriers}

There was no public system for the conveyance of private letters in antiquity. ${ }^{47}$ White ${ }^{48}$ says that the best organized postal system in antiquity was the Roman cursus publicus which was established by Emperor Augustus. But this system could not be used for private letters. It was used to carry military dispatches and other official documents. There is little evidence for a private use of the Roman postal system. Private individuals used friends, casual acquaintances or servants as letter-carriers. ${ }^{49}$ It was not always easy to find trustworthy letter-carriers $(\gamma \rho \alpha \mu \alpha \mu \tau \eta \phi o ́ \rho \omega \nu) .{ }^{50}$ Letter-writers always feared that letters would not be delivered quickly and safely ( $\left.\tau \alpha \chi^{\prime} \epsilon \omega \varsigma \kappa \alpha \dot{\imath} \dot{\alpha} \sigma \phi \alpha \lambda \omega \varsigma\right)$ and that it would

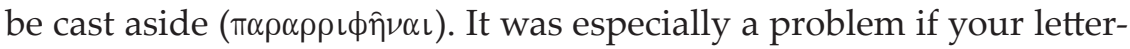
carrier arrived with a letter and the addressee was not on the spot. One would then expect the letter-carrier to at least take the letter to friends so that they would then take on the responsibility of delivering the letter to the addressee. That is why Chrysostom asks that his letter be delivered "by the hands of some discreet man, who has a head on his

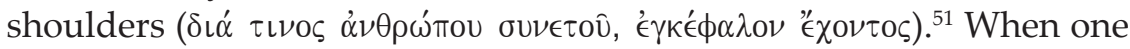
was lucky enough to find a letter-carrier, one would use the opportu-

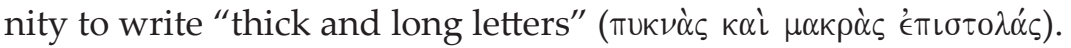

Different kinds of people were used as letter-carriers. Chrysostom even asked proconsular soldiers ( $\tau \omega \hat{\nu} \epsilon^{\prime} \pi \alpha \rho \chi\llcorner\kappa \hat{\omega} \nu$ ) and Anatolius his servant to deliver letters to Olympias. ${ }^{52}$ One could also ask the recipient of his letter to pass on other letters to other addressees..$^{53}$ Chrysostom asked the deacons Paul and Cyriacus to take his letter to Innocent, bishop of Rome. ${ }^{54}$ And he asked the presbyter John and the deacon

(47) S. R. Llewelyn, Sending Letters in the Ancient World: Paul and the Philippians, Tyndale Bulletin 46.1 (1995) 339-340.

(48) J. L. White, Light from Ancient Letters (Philadelphia: Fortress Press, 1986) 214. See also S. R. Llewelyn, The Official Postal System of Antiquity, in: IDEM, New Documents Illustrating Early Christianity (Australia: Macquarie University, 1994).

(49) E. M. Jersey and A. P. Kazhdan, Epistolography, in: A. P. Kazhdan (ed.), The Oxford Dictionary of Byzantium (Oxford: Oxford University Press, 1991) 719.

(50) Epistulae ad Olympiadem 8. 11. 15-17.

(51) Ibid., 9. 5. 51-53.

(52) Ibid., 9. 4. 32-33.

(53) Ibid., 9. 5. 5-6.

(54) Ad Innocentiam papam 52. 530. 38-42. 
Paul to deliver the second letter which they had received from him to Bishop Innocent. ${ }^{55}$

Chrysostom tells us an interesting account about how a bishop returned to Antioch with a letter from the Emperor in which the Emperor granted them grace despite a sedition in the city. The bishop realized that his journey would take too long and he wanted the city to receive the good news. He therefore asked a man who was skilled

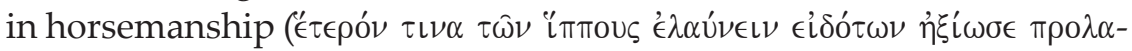
$\beta \in \hat{\imath} \nu)$ to take the letter to the city so that the inhabitants could rejoice. ${ }^{56}$

\section{Letter-Carriers Were Also Messengers}

The writer of a letter would always like to keep his letter short, and would therefore not write everything in his letter. He would then give orally additional information to the letter-carrier and that would make the person even more respected ( $\alpha i \delta \in \sigma \iota \mu \omega \dot{\tau} \epsilon \rho \nu \nu)$ because he too could relate some news and amplify the message. ${ }^{57}$ Chrysostom says that is why Paul said to the Colossians that Tychicus would tell them all the news about him (Col. 4:7).

Jeffreys and Kazhdan ${ }^{58}$ say that the real subject matter of a letter was often delivered orally by the courier, and that letters frequently contained generalities rather than specific details. I think Jeffreys and Kazhdan are wrong. If their assumption were correct, it would make letters superfluous. Chrysostom says that Paul conveyed all matters related to doctrine and exhortation by means of letters. But those which were matters of bare recital, he entrusted to the bearer of the letter. That is why we read in Ephesians 6: 21 that Paul says that Tychicus will make to them known all things. ${ }^{59}$

But letter-carriers could also endorse the contents of the letter which they carried. Judas and Silas, for example, spoke to the congregation after they had delivered their message (Acts 15:32). Chrysostom says that it was necessary for Judas and Silas to also exhort by word ( $\pi \alpha \rho \alpha-$

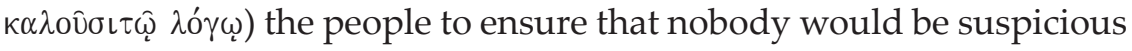

(55) Ad Innocentiam papam 52. 535. 43-46.

(56) Ad populum Antiochenum 49. 220. 33-34.

(57) In epistulam ad Colossenses, PG 62, 374. 48-49; cf. B. Leyerle, Communication and Travel, in: Esler, The Early Christian World..., 470.

(58) Jersey and Kazhdan, Epistolography..., 720.

(59) In epistulam ad Ephesios, PG 62, 170. 10-15. 
of Paul and Barnabas. ${ }^{60}$ Paul and Barnabas could also have done that, but the fact that two respected people repeated the message, confirmed the credibility of Paul and Barnabas.

\section{The Forging of Letters}

It was easy to forge letters. ${ }^{61}$ Both Josephus and Suetonius tell us about letters that were forged to do damage to someone. ${ }^{62}$ An author would do everything possible to prevent the forging of his letters. He would, for example, personally sign the letter. ${ }^{63}$ There were several attempts to pretend that letters were written by Paul. ${ }^{64}$ That is why Paul refers to letters "supposed to have come from us" (2 Thess. 2:2). Regarding Acts 15:32 Chrysostom says that had Paul and Barnabas came alone with an oral message, the congregation in Antioch might have thought that they gave their account of the decision only. But if these two did bring a letter with them, it could still be doubted whether the letter was genuine. That is why two respected people, Judas and Silas, were sent with a letter, and with Paul and Barnabas! ${ }^{65}$

\section{Emotions}

Chrysostom often refers to how difficult it is to express one's feelings in a letter. He, for example, wrote a letter to his friend Theodore, who later became bishop of Mopsuestia. Theodore had fallen in love with a certain Hermione and decided to give up the monastic life. Chrysostom wrote a letter to him, urging him to return to monasticism. He admits that it is very difficult to express one's emotions in a letter and says: "If it were possible to express tears and groans by means of writing I would have filled the letter..." 66

He says that Paul too could not show his tears or cries of grief in his letters. That is why he ardently desired to be present with them (cf. Gal. 4:20). Paul says that if he were present with the Galatians, he

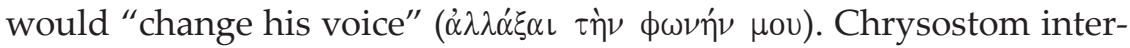

(60) In Acta apostolorum, PG 60, 243. 2.

(61) In epistulam ii ad Thessalonicenses, PG 62, 469. 30-31.

(62) Cf. G. J. BAHr, Paul and Letter Writing in the Fifth Century, The Catholic Bible Quarterly 28 (1966) 476.

(63) In epistulam ii ad Thessalonicenses, PG 62, 469. 36-42.

(64) Ibid., 481. 60-63.

(65) In Acta apostolorum, PG 60, 242. 38ff.

(66) Ad Theodorum lapsum lib. ii. sec i. 1. 
prets it as "a change to lamentation, to shed tears, to turn everything

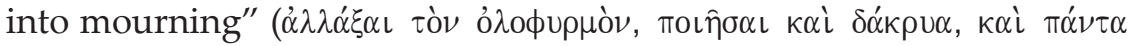

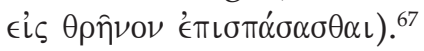

\section{The Length of Letters}

There is an optimal length for a letter. Gregory Nazianzenus, for example, said that "one should not write on and on when the subject matter is limited, nor be stingy with words when there is much to say." ${ }^{68}$ Chrysostom was very sensitive not to exceed the normal length of a letter, and he would even omit important matters in order to stay within the conventional length of a letter. ${ }^{69}$ However, when Chrysostom passionately pleaded with his friend Theodore to return to the monastic life, he admitted that he had "exceeded the due measure of

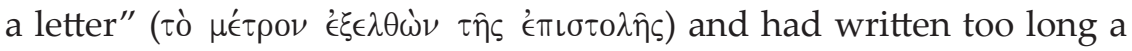
letter. ${ }^{70}$ It was also Chrysostom's intention to send long letters to Olympias. He said that he would send her letters that would exceed the

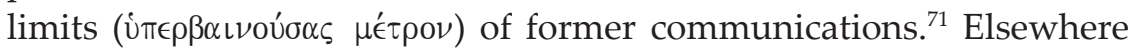
he asks her to inform him whether she likes long letters, and promises her that if she does, he would definitely write longer letters. ${ }^{72}$ It is interesting to see how often Chrysostom writes about the length of letters. In his letter to bishop Innocent about the events in Alexandria, Chrysostom says that he could not give too much detail in his letter,

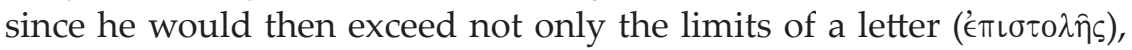

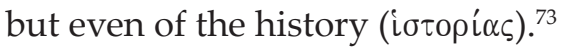

Paul too did not put everything in his letters, but only matters which were necessary ( $\tau \dot{\alpha} \dot{\alpha} \nu \alpha \gamma \kappa \alpha \hat{\imath} \alpha)$ and urgent $(\tau \dot{\alpha} \kappa \alpha \tau \epsilon \pi \epsilon \dot{l} \gamma o \nu \tau \alpha) .{ }^{74} \mathrm{He}$ did not want to draw his letters out. It is clear that it was a тómo in ancient letter-writing to say something about the length of your letter.

(67) In epistulam ad Galatas commentarius, PG 61, 660. 54-55.

(68) Gregory Nazianzenus, Epistula 51.

(69) Epistulae ad Olympiadem 10. 14. 56-59; cf. also Epistulae ad Olympiadem 15. 1. 27-28.

(70) Ad Theodorum lapsum lib. ii. sec vi. 1.

(71) Epistulae ad Olympiadem 17. 4. 55.

(72) Ibid., 2. 1. 15-16.

(73) Ad Innocentium papam 52. 536. 19-20.

(74) In epistulam ad Colossenses, PG 62, 374. 46. 


\section{Analysis of Letters}

Trapp ${ }^{75}$ believes that Christian epistolography was strongly influenced by the schools of rhetoric and as a literary genre assumed all the formal characteristics of literary prose. ${ }^{76}$ It is clear that the ancients made a proper study of letters as a genre. Chrysostom regards letters as a separate genre, alongside other genres such as histories

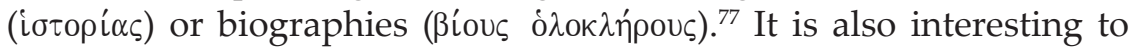
see how Chrysostom analysed Paul's letters: He calls the beginning of Paul's letter the $\pi \rho \circ o$ í $\mu\left\llcorner o v\right.$ (introduction), ${ }^{78}$ and he says that Paul always

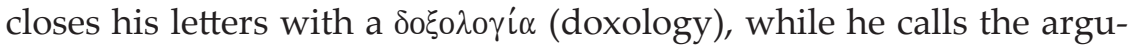
ment or the subject theme of the letter the imó $\theta \in \sigma \iota \varsigma .{ }^{79}$ He also refers to

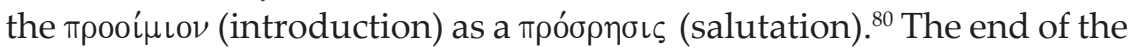
letter is called the $\tau \tau^{\prime} \lambda \mathrm{os} .{ }^{81}$

Chrysostom says that usually Paul divides his letters into two

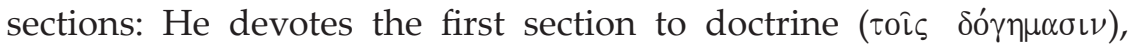
and the second section to the care of moral instruction ( $\tau \hat{n} \tau \hat{\omega} \nu \dot{\eta} \theta \hat{\omega} \nu$ $\left.\epsilon \pi \iota \mu \in \lambda \in \epsilon^{\prime} \alpha\right){ }^{82}$ Elsewhere ${ }^{83}$ he repeats that Paul divided his letters into two parts, and then he says that the first part is concerned with doc-

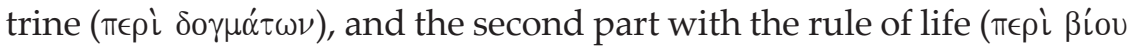
$\delta\llcorner\alpha \lambda \in \gamma o ́ \mu \epsilon \nu 0 \varsigma)$. In the book of Romans, however, Paul mixes these two

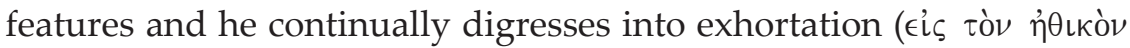

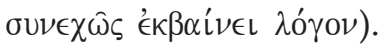

(75) M. B. Trapp, Letters, Greek, in: S. Hornblower and A. Spawforth (eds.), The Oxford Classical Dictionary (Oxford: Oxford University Press, 2003³) 847.

(76) M. P. Ciccarese, Letter, Epistle, in: A. Di Bernardino (ed.), Encyclopedia of the Early Church (Cambridge: James Clarke \& Co.) 483.

(77) In epistulam I ad Corinthios, PG 61, 56. 13.

(78) In epistulam I ad Corinthios, PG 61, 215. 45; 384. 7; In epistulam ad Galatas commentarius, $P G$ 61, 611. 13-15.

(79) In Matthaeum, PG 58, 547. 37-41; In epistulam ii ad Corinthios, PG 61, 384. 5.

(80) In epistulam ii ad Corinthios, PG 61, 384. 8.

(81) Ibid., 417. 55; 605.10.

(82) In epistulam ad Romanos, PG 60, 483. 330-336.

(83) In epistulam ad Galatas commentarius, PG 61, 669. 38-41. 
Chrysostom says that when Paul speaks, he applies the same technique as in his letters, namely he exhorts people and then he ends with

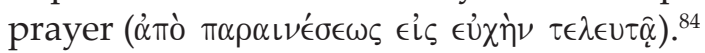

\section{The Character of Paul's Letters}

Each letter has its own tone. Chrysostom made a careful study of Paul's letters, including the book of Hebrews which he also regarded as a letter by Paul.$^{85}$ Chrysostom identified and discussed the character and tone of each letter. He noticed, for example, that in Paul's First Letter to the Corinthians, Paul started with accusations which were leveled against the Church, and thereafter Paul moved to milder themes. He then shows that in Paul's Second Letter to the Corinthians, Paul started with milder themes, and then moved over to more distressing topics. ${ }^{86}$ Chrysostom says that one would not be wrong to style the

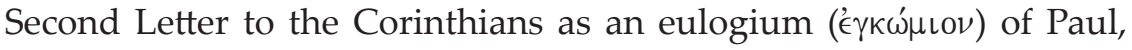
since he makes such large mention of his grace and patience. ${ }^{87}$

However, he says that Paul's Letter to the Galatians is characterized

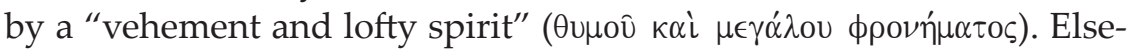

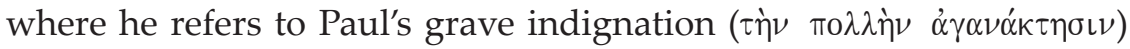
when he wrote the letter. ${ }^{88}$ Paul's Second Letter to Timothy is full of

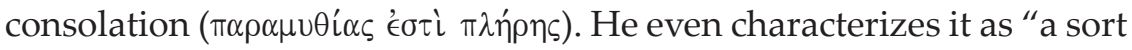

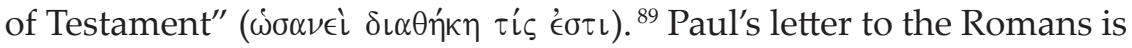
meant to exhort ( $\left.\pi \alpha \rho \alpha \nu \nu \nu^{\prime} \omega\right)$ his readers. ${ }^{90}$

Chrysostom characterizes the letter in Acts 15 as "short" ( $\beta \rho \alpha \chi \in i \alpha \nu)$, with "nothing more in it than was needed, neither arts of persuasion,

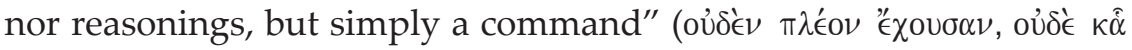

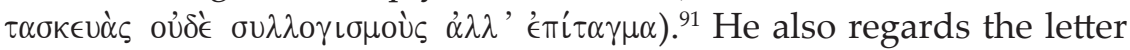
in Acts 23 as a defence ( $\dot{\alpha} \pi 0 \lambda \sigma \gamma i \alpha \nu)$ of Paul, as well as an accusation

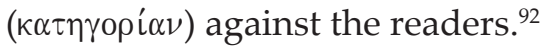

(84) In Acta apostolorum, PG 60, 313, 33.

(85) In Acta apostolorum, PG 60, 327. 12; In epistulam ad Romanos, PG 60, 395. 15.

(86) In epistulam $i$ ad Corinthios, PG 61, 151. 25-41.

(87) Ibid., 541. 23-24.

(88) In epistulam ad Galatas commentarius, PG 61, 616. 43.

(89) In epistulam ii ad Timotheum, PG 62, 652. 46-48.

(90) In Matthaeum, PG 57, 411. 22.

(91) In Acta apostolorum, PG 60, 242. 60-62.

(92) Ibid., 341. 17-19. 
Chrysostom believed that Paul was not skilled in writing. He argues that Paul's reference to the size of his letters (Gal. 6:11) refers not to the

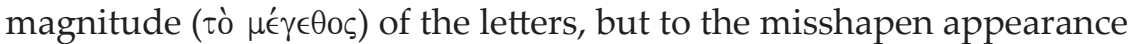

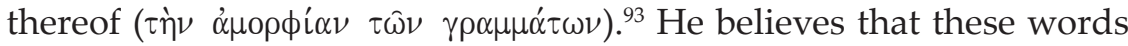
signify that Paul himself wrote the whole letter in order to prove his sincerity, while in other epistles he dictated his message to somebody else to write it down. ${ }^{94}$ But Paul would always sign his letters to prove the authenticity thereof. ${ }^{95}$ Bahr $^{96}$ says that ancient writings show that sometimes more than just the signature of the sender was added to the letter. Often there was a kind of postscript in the sender's own hand.

\section{Spiritual Meaning}

With all his knowledge of letters and letter-writing, Chrysostom was able to interpret Paul's remark that the Corinthians are his epistle. By reading an epistle, one gains knowledge about the author of the epistle. Thus Chrysostom says that the Corinthians are an epistle, since they are able to show to all people by their own virtue the high worth of their teacher. ${ }^{97}$ But they are also called an "epistle of Christ" since they have the Law of God written in their hearts. Just as Moses hewed the stones and prepared the tables for the law, similarly Paul prepared the Corinthians to receive the writing. God wrote the laws of Moses, but in the case of the Corinthians, the Holy Spirit was the author. The former was written with ink, the latter with the Spirit of the Living God. The former was written on tables of stone, the latter in hearts of flesh. ${ }^{98}$

\section{Conclusion}

Chrysostom never wrote a detailed essay on the art of letter-writing as did Gregory Nazianzenus. ${ }^{99}$ Yet his works are full of information regarding the nature and function of letters in the ancient world. Much of this information can indeed be used in modern-day research on the epistles in the New Testament. Most studies on ancient letters

(93) In epistulam ad Galatas commentarius, PG 61, 678. 19-20.

(94) Ibid., 677. 55 - 678. 12.

(95) In epistulam ii ad Thessalonicenses, PG 62, 469. 33-43.

(96) Cf. BAHr, Paul and Letter Writing in the Fifth Century..., 467.

(97) In epistulam ii ad Corinthios, PG 61, 436. 25-43.

(98) Ibid., 437. 17-39.

(99) Gregory Nazianzenus, Epistula 51. 
are based on the letters of the classical writers. It is a pity that the letters of the ancient theologians are so neglected in modern studies. It is not only the letters of the ancient Fathers that give us insight into letter-writing in the ancient world, but their other writings are also full of references to this issue. Moreover, these letters can give us valuable information regarding the social life of the ancients.

\section{SUMMARY}

Much information regarding letter-writing and the function of letters in the ancient world can be deduced from the works of the early theologians. In this paper the works of Chrysostom will be scrutinized for statements regarding the writing and reading of ancient letters. This information will also be used to reveal something about the social lives of the ancients. It is also relevant for the interpretation of the New Testament letters. 